\title{
Serosurvey of tick-borne pathogens in dogs from urban and rural areas from Parana State, Brazil
}

\author{
Avaliação sorológica de patógenos transmitidos por carrapatos em cães \\ urbanos e rurais do estado do Paraná, Brasil
}

Thállitha Samih Wischral Jayme Vieira ${ }^{1}$; Rafael Felipe da Costa Vieira²; Denise Amaral Gomes do Nascimento; Kátia Tamekuni ${ }^{1}$; Roberta dos Santos Toledo' ${ }^{1}$; Ramaswamy Chandrashekar ${ }^{3}$; Mary Marcondes ${ }^{4}$;

Alexander Welker Biondo ${ }^{5,6}$; Odilon Vidotto ${ }^{1 *}$

\begin{abstract}
${ }^{1}$ Department of Preventive Veterinary Medicine, Universidade Estadual de Londrina - UEL, Londrina, PR, Brazil
${ }^{2}$ Department of Veterinary Sciences, Universidade Federal da Paraíba - UFPB, Areia, PB, Brazil

${ }^{3}$ IDEXX Laboratories Inc., Westbrook, ME, USA
\end{abstract}

${ }^{4}$ Department of Clinics, Surgery and Animal Reproduction, Universidade Estadual Paulista - UNESP, Araçatuba, SP, Brazil

${ }^{5}$ Department of Veterinary Medicine, Universidade Federal do Paraná - UFPR, Curitiba, PR, Brazil

${ }^{6}$ Department of Veterinary Pathobiology, University of Illinois, Champaign, IL, USA

Received July 12, 2012

Accepted September 12, 2012

\begin{abstract}
Considering the zoonotic potential of tick-borne disease (TBD) agents and the fact that dogs may act as sentinels for human infection, the aim of the present study was to determine the seroprevalence of TBD agents and risk factors for exposure in two different canine populations from Parana State, Southern Brazil. A total of 138 dog serum samples from urban (UA) ( $\mathrm{n}=68)$ and rural (RA) ( $\mathrm{n}=70)$ areas were tested with commercial ELISA rapid test for Anaplasma phagocytophilum, Ehrlichia canis and Borrelia burgdorferi antibodies and indirect immunofluorescence assay (IFAT) for Babesia vogeli. An overall of 92/138 (66.7\%) dogs, being 62/68 (91.2\%) from UA and 30/70 (42.9\%) from RA, were seropositive for at least one TBD agent. From the total number of dogs, sixty-two were positive for E. canis (44.9\%), 19 (13.8\%) for A. phagocytophilum, and 64 (46.4\%) for B. vogeli. Anti-B. burgdorferi antibodies were not detected. Dogs from UA showed a higher percentage of tick infestation $(\mathrm{p}=0.0135)$ and were highly associated with seropositivity to E. canis $(\mathrm{p}=0.000005)$, A. phagocytophilum $(\mathrm{p}=0.0001)$, and B. vogeli $(\mathrm{p}=0.0012)$. In summary, the findings indicate that dogs from urban areas present higher potential risk exposure to TBD pathogens than those from rural areas.
\end{abstract}

Keywords: Ehrlichia canis, Babesia vogeli, Anaplasma phagocytophilum, Borrelia burgdorferi, serology, Parana.

\section{Resumo}

Considerando o potencial zoonótico das doenças transmitidas por carrapatos (DTCs) e que os cães podem atuar como sentinelas para infecçóes em humanos, os objetivos deste estudo foram determinar a soroprevalência de agentes das DTCs e fatores de risco para a exposição em duas diferentes populações caninas do Estado do Paraná, região Sul do Brasil. Um total de 138 amostras de soro de cáes de área urbana $(\mathrm{AU})(\mathrm{n}=68)$ e rural $(\mathrm{AR})(\mathrm{n}=70)$ foram testadas utilizando um teste de ELISA comercial rápido para detecção de anticorpos contra Anaplasma phagocytophilum, Ehrlichia canis e Borrelia burgdorferi e imunofluorescência indireta (IFI) para Babesia vogeli. Um total de 92/138 (66,7\%) cães, sendo 62/68 (91,2\%) da AU e 30/70 (42,9\%) da AR, foram soropositivos para pelo menos um agente. Do número total de amostras, sessenta e duas (44,9\%) foram positivas para E. canis, 19 (13,8\%) para A. phagocytophilum e $64(46,4 \%)$ para $B$. canis vogeli. Anticorpos anti- $B$. burgdorferi não foram detectados. Os cães da $\mathrm{AU}$ apresentaram o maior percentual de infestação por carrapatos $(\mathrm{p}=0,0135)$ e foram altamente associados com a positividade para $E$. canis $(\mathrm{p}=0,000005)$, A. phagocytophilum $(\mathrm{p}=0,0001)$ e $B$. vogeli $(\mathrm{p}=0,0012)$. Em resumo, nossos achados indicam que cáes de áreas urbanas têm um maior risco potencial de exposiçáo a agentes patogênicos das DTCs comparados aos das áreas rurais.

Palavras-chave: Ehrlichia canis, Babesia vogeli, Anaplasma phagocytophilum, Borrelia burgdorferi, sorologia, Paraná.

\footnotetext{
*Corresponding author: Odilon Vidotto

Department of Preventive Veterinary Medicine, Universidade Estadual de

Londrina - UEL, Rod. Celso Garcia Cid (PR 445), Km 380,

Campus Universitário, CEP 86051-990, Londrina, PR, Brasil

e-mail: vidotto@uel.br
} 


\section{Introduction}

Ehrlichiosis, anaplasmosis, babesiosis, and borreliosis are important tick-borne diseases (TBDs) affecting dogs worldwide (LABARTHE et al., 2003; CARLOS et al., 2007; AMUSATEGUI et al., 2008; BOWMAN et al., 2009; WONG et al., 2011). While ticks of the genus Amblyomma are commonly found in rural areas, Rhipicephalus sanguineus, the brown $\operatorname{dog}$ tick, is the most common species infesting domestic dogs in urban areas in Brazil (LABRUNA et al., 2001). It is involved in the transmission of Ehrlichia canis and Babesia vogeli (DANTASTORRES, 2008). E. canis is the causative agent of canine monocytic ehrlichiosis (CME), widespread in most regions of the country, with seroprevalence varying from $0.7 \%$ to $86.2 \%$, depending on the population studied, geographic area and diagnostic test used (VIEIRA et al., 2011). B. vogeli is the most common reported agent of canine babesiosis and seroprevalence data, ranging from $18.8 \%$ to $73.3 \%$ (TRAPP et al., 2006; MAIA et al., 2007; FURUTA et al., 2009; SPOLIDORIO et al., 2010).

It has been suggested that $R$. sanguineus, widely found across the country, may be a potential vector for Anaplasma platys to dogs in Brazil (DANTAS-TORRES, 2008). The identification of this organism can be achieved by the observation of $A$. platys inclusions in platelets during the examination of stained peripheral blood smears and by molecular methods (DAGNONE et al., 2009). Prevalence of $A$. platys infection ranges from $18.8 \%$ to $48.8 \%$ (DAGNONE et al., 2009; SANTOS et al., 2009; RAMOS et al., 2010); however, the seroprevalence remains to be fully established, since there is no developed serological diagnostic assay for this agent to date. Serological assays, such as ELISA, immunofluorescence antibody test (IFAT) and dot-ELISA, originally developed for the detection of anti- $A$. phagocytophilum antibodies, have been used as an alternative, due to the cross-reaction between $A$. phagocytophilum and $A$. platys antibodies (CHANDRASHEKAR et al., 2010).

A. phagocytophilum (a combination of organisms previously known as E. equi, E. phagocytophila and human granulocytic ehrlichiosis [HGE] agent) is the causative agent of granulocytic anaplasmosis and has been reported infecting dogs, cats, horses, ruminants and humans worldwide (WOLDEHIWET, 2010). Ixodes scapularis, I. pacificus and I. ricinus ticks act as the main vectors for this agent (AMUSATEGUI et al., 2008; BOWMAN et al., 2009) and although these ticks are not present in Brazil, other Ixodes and Amblyomma species are frequently found (FIGUEIREDO et al., 1999; ABEL et al., 2000). Recently, A. phagocytophilum was detected, by molecular methods, infecting dogs in Brazil (SANTOS et al., 2011).

Ticks of the Ixodes genus are also involved in the transmission of Borrelia burgdorferi sensu lato (s.l.), the causative agent of Lyme disease (BURGDORFER et al., 1989). In Brazil, it is suspected that both Amblyomma cajennense and Rhipicephalus (Boophilus) microplus are involved in the transmission of B. burgdorferi (s.l.) (BARROS-BATTESTI et al., 2000; YOSHINARI et al., 2003). There are serological evidences of B. burgdorferi (s.l.) infection in Brazilian dogs, with prevalence data ranging from $0.04 \%$ to $53.5 \%$ (LABARTHE et al., 2003; CARLOS et al., 2007; SPOLIDORIO et al., 2010). Nevertheless, it is important to mention that B. burgdorferi (s.l.) has never been isolated or molecularly detected in this country, and thus, the role of these ticks on the transmission of Lyme disease remains to be established.

Considering the zoonotic potential of these agents and that dogs may act as sentinels for tick-borne infections to humans (AMUSATEGUI et al., 2008), the aims of the present study was to determine the seroprevalence of $A$. phagocytophilum, E. canis, B. burgdorferi and B. vogeli, the identification of tick species found in dogs, and the evaluation of the risk factors for exposure to the organisms, in two different canine populations from Paraná State, Southern Brazil.

\section{Materials and Methods}

\section{Ethical principles}

The study was approved by the Ethics Committee in Animal Experimentation and Animal Welfare of the "Universidade Estadual de Londrina” - UEL (number 34/2011).

\section{Study area}

The study was carried out in rural and urban areas located in the central-northern region of the State of Parana. The urban area (UA) is located in a region of 'Jardim California', a neighborhood located in the eastern side of Londrina ( $23^{\circ} 08^{\prime} 47^{\prime \prime} \mathrm{S}$ and $\left.51^{\circ} 19^{\prime} 11^{\prime \prime} \mathrm{W}\right)$. The area is situated at $610 \mathrm{~m}$ above sea level; presents a subtropical climate with rainfall throughout the year, but concentrated during summer. The average annual temperature is around $20^{\circ} \mathrm{C}$ (INMET, 2011). Dogs have free access to an abandoned square, covered by a mixed overgrowth pasture composed by grass and undesired plants (bushes, scrubs); dogs are also in constant contact with horses. This square is also used for neighbors' leisure, and present high amount of ticks.

The rural area (RA) is a settlement situated in the 'Alvorada do Sul' county ( $22^{\circ} 54^{\prime} 34.4^{\prime \prime} \mathrm{S}$ and $\left.51^{\circ} 13^{\prime} 49.1^{\prime \prime} \mathrm{W}\right)$. The area is located within the rural perimeter of Alvorada do Sul, $16 \mathrm{~km}$ far from downtown, $380 \mathrm{~m}$ above sea level. The region presents subtropical climate with rainfall throughout the year, but with a tendency of concentrating rain during the summer months with an average temperature of $25^{\circ} \mathrm{C}$ (INMET, 2011). The area is subdivided in 60 land properties with approximate area of 12 ha each, totalizing 786 ha. The rural settlement lacks basic sanitation and the main activity of dwellers is the cultivation of grains and vegetables. The area also comprises $20 \%$ of native forest, presenting diverse fauna, with a varied population of wild animals. In this region, a large number of ticks can be found throughout the year.

\section{Animals}

A total of 138 dogs of different ages, breeds, and both sexes from urban and rural areas of the central-northern region of the State of Parana were used. A total of 68 dogs from UA and 70 dogs from RA were sampled during an active surveillance program for infectious diseases. 


\section{Collection of ticks}

A total of 126 adult ticks were collected from dogs, being 59 from the UA and 67 from the RA. Ticks were removed using tweezers and placed in tubes containing 70\% ethanol solution and identified according to morphological keys (ARAGÃO; FONSECA, 1961; GUIMARÁES et al., 2001).

\section{Study design}

Owners responded to a previous validated epidemiological questionnaire during the sampling, addressing breed, age, gender and presence of ticks. Age was classified in groups: $\leq 1$ and $>1$ year old.

\section{Sampling}

Dog blood samples $(10 \mathrm{~mL})$ were collected by venipuncture of jugular vein into tubes without anti-coagulant and kept at room temperature $\left(25^{\circ} \mathrm{C}\right)$ until visible clot retraction, centrifuged at $1500 \mathrm{~g}$ for 5 minutes. Sera were separated and kept at $-20{ }^{\circ} \mathrm{C}$ until testing.

\section{Detection of antibodies against $A$. phagocytophilum, E. canis and B. burgdorferi (s.l.)}

All 138 dogs serum samples were tested for A. phagocytophilum, B. burgdorferi (s.l.), and E. canis using a commercial ELISA rapid test $\left(\mathrm{SNAP}^{\circledR} 4 \mathrm{Dx}{ }^{\circledR}\right.$, IDEXX Laboratories Inc., Westbrook, ME, USA), according to the manufacturer's instructions.

\section{Detection of antibodies against $B$. vogeli}

Antibodies anti-B. vogeli were detected by indirect immunofluorescence antibody test (IFAT) using antigens obtained from a splenectomized dog inoculated with $B$. vogeli, as previously described (TRAPP et al., 2006), with modifications. Briefly, IFAT was performed with $10 \mu \mathrm{L}$ of serum samples incubated at $37^{\circ} \mathrm{C}$ for 30 minutes in slides previously seeded with $B$. vogeli and washed three times for 5 minutes in phosphate buffered saline (PBS, pH 7.2). Ten microliters of fluorescein isothiocyanateconjugated rabbit anti-dog IgG (Sigma-Aldrich, St. Louis, MO) at $1: 1000$ dilution in $0.01 \%$ Evans blue was applied onto the slide. Slides were then incubated at $37^{\circ} \mathrm{C}$ for 30 minutes, washed three times for 5 minutes, allowed to air dry and, subsequently, examined in microscope with fluorescent light source. Serum samples with fluorescent protozoa at dilution $\geq 1$ :80 were considered positive. Titers were determined to the largest dilution in which fluorescence was visualized around the protozoa.

\section{Statistical analysis}

Either Chi-square or Fisher's exact test was used to determine the difference between whether individual factors were associated with seropositivity to A. phagocytophilum, B. burgdorferi (s. 1.),
E. canis and/or B. canis. Odds ratio (OR), 95\% confidence interval and $\mathrm{p}$ values were calculated separately for each variable. Results were considered statistically significant when $p<0.05$. Data were compiled and analyzed using Epi Info 'm Software (version 3.5.3).

\section{Results}

From the total of 138 dogs sampled, 90 (65.2\%) were males and 48 (34.8\%) females. Breeds included Cocker Spaniel (2), Pit Bull (1), Poodle (2), and mixed breed (133) dogs. A total of 92/138 (66.7\%; 95\% CI: 58.1-74.5\%) dogs were seropositive for different TBD agents: 62/68 (91.2\%; 95\% CI: 81.8-96.7\%) from UA and 30/70 (42.9\%; 95\% CI: 31.1-53.3\%) from RA. Dogs from the UA were 13.7 times more likely to be seropositive for at least one TBD agent than those dwelling RA (95\% CI: 5.26-36.07\%; $\mathrm{p}=0.0001$ ).

Using the commercial ELISA rapid test, it was possible to verify that 62/138 (44.9\%; 95\% CI: 36.5-53.6\%) dogs were seropositive for E. canis. Seroprevalence in UA and RA were 44/68 (64.7\%; 95\% CI: 52.2-75.9\%) and 18/70 (25.7\%; 95\% CI: 16.0-37.6\%), respectively. Antibodies against $A$. phagocytophilum were found in 19/138 (13.8\%; 95\% CI: 8.5-20.7\%) dogs: 17/68 (25\%; 95\% CI: $15.3-37 \%)$ from UA and $2 / 70$ (2.9\%; 95\% CI: $0.3-9.9 \%)$ from RA. B. burgdorferi antibodies were not detected in dogs from both locations (Table 1).

Anti-B. vogeli antibodies were detected in 64/138 (46.4\%; 95\% CI: $37.9-55.1 \%)$ dogs by IFAT. Seroprevalence in UA and RA were 41/68 (60.3\%; 95\% CI: 47.7-72\%) and 23/70 (32.9\%; $95 \%$ CI: $22.1-45.1 \%$ ), respectively (Table 1 ). Antibodies titers ranged from 80 to 20480 in dogs from UA and from 80 to 2560 in dogs from RA. Additionally, 37/138 (26.8\%; 95\% CI: 20.1-34.7\%) dogs were seropositive for E. canis and B. vogeli, 8/138 (5.8\%; 95\% CI: $2.9-11 \%)$ for $A$. phagocytophilum and B. vogeli, and 15/138 (10.8\%; 95\% CI: 6.7-17.1\%) dogs were seropositive for A. phagocytophilum and E. canis.

Dogs from the UA showed higher percentage of tick infestation - 48/68 (70.6\%), compared to the RA - 35/70 (50\%), $(\mathrm{p}=0.0135)$. From the total of the 126 ticks collected from the UA and RA, 58/59 (98.3\%) and 45/67 (67.1\%), respectively, were identified as Rhipicephalus sanguineus. Nonetheless, only 1/59 (1.7\%) and 1/67 (1.5\%) were identified as Amblyomma cajennense, in UA and RA, respectively. Twenty-one out of 67 (31.3\%) ticks from RA were identified as Amblyomma ovale.

Dogs living in the urban area were highly associated with seropositivity to $E$. canis ( $\mathrm{p}=0.000005)$, A. phagocytophilum $(\mathrm{p}=0.0001)$, and B. vogeli $(\mathrm{p}=0.0012)$. Dogs $>1$ year old were highly associated with seropositivity to $E$. canis (p = 0.00001). No significant association was found between age or gender and seropositivity to $A$. phagocytophilum and B. vogeli. Results for the seroprevalence of $A$. phagocytophilum and $E$. canis in dogs from rural and urban areas within each variable studied are shown in Table 1.

\section{Discussion}

In Brazil, data on the distribution of arthropods and canine TBDs are still incomplete. In this study, $91.2 \%$ of the dogs from 
Table 1. Serological prevalence of Anaplasma phagocytophilum, Ehrlichia canis, Babesia vogeli in dogs within each variable studied, State of Parana, southern Brazil.

\begin{tabular}{|c|c|c|c|c|c|c|c|c|c|c|c|c|}
\hline \multirow[t]{2}{*}{ Variable } & \multicolumn{4}{|c|}{ Anaplasma phagocytophilum } & \multicolumn{4}{|c|}{ Ebrlichia canis } & \multicolumn{4}{|c|}{ Babesia vogeli } \\
\hline & $+/ \mathrm{N}(\%)$ & OR & $95 \% \mathrm{CI}$ & $P$-value & $+/ \mathrm{N}(\%)$ & OR & $95 \% \mathrm{CI}$ & P-value & $+/ \mathrm{N}(\%)$ & OR & $95 \% \mathrm{CI}$ & $P$-value \\
\hline \multicolumn{13}{|l|}{ Place } \\
\hline Urban Area & $17 / 68(25)$ & 11.33 & $2.50-51.27$ & 0.0001 & $\begin{array}{l}44 / 68 \\
(64.7)\end{array}$ & 5.29 & $\begin{array}{c}2.54- \\
11.00\end{array}$ & 0.000005 & $\begin{array}{l}41 / 68 \\
(60.3)\end{array}$ & 3.10 & $1.54-6.22$ & 0.0012 \\
\hline Rural Area & $2 / 70(2.9)$ & & & & $\begin{array}{l}18 / 70 \\
(25.7)\end{array}$ & & & & $\begin{array}{l}23 / 70 \\
(32.9)\end{array}$ & & & \\
\hline \multicolumn{13}{|c|}{ Presence of ticks } \\
\hline Yes & $\begin{array}{l}15 / 83 \\
(18.1)\end{array}$ & 2.81 & $0.88-8.98$ & 0.0714 & $\begin{array}{l}37 / 83 \\
(44.6)\end{array}$ & 0.96 & $0.48-1.91$ & 0.9192 & $\begin{array}{l}40 / 83 \\
(48.2)\end{array}$ & 1.20 & $0.60-2.38$ & 0.5992 \\
\hline No & $\begin{array}{l}4 / 55 \\
(7.3)\end{array}$ & & & & $\begin{array}{l}25 / 55 \\
(45.5)\end{array}$ & & & & $\begin{array}{l}24 / 55 \\
(43.6)\end{array}$ & & & \\
\hline \multicolumn{13}{|l|}{ Age (years) } \\
\hline$>1$ & $\begin{array}{l}14 / 86 \\
(16.3)\end{array}$ & 1.83 & $0.61-5.41$ & 0.2709 & $\begin{array}{l}51 / 86 \\
(59.3)\end{array}$ & 5.43 & $2.46-11$ & 0.00001 & $\begin{array}{l}45 / 86 \\
(52.3)\end{array}$ & 1.91 & $0.94-3.86$ & 0.0715 \\
\hline$\leq 1$ & $\begin{array}{l}5 / 52 \\
(9.6)\end{array}$ & & & & $\begin{array}{l}11 / 52 \\
(21.2)\end{array}$ & & & & $\begin{array}{l}19 / 52 \\
(36.5)\end{array}$ & & & \\
\hline \multicolumn{13}{|l|}{ Gender } \\
\hline Male & $\begin{array}{l}11 / 90 \\
(12.2)\end{array}$ & 0.69 & $0.26-1.87$ & 0.4704 & $\begin{array}{l}42 / 90 \\
(46.7)\end{array}$ & 1.03 & $0.51-2.09$ & 0.9255 & $\begin{array}{l}38 / 90 \\
(42.2)\end{array}$ & 0.73 & $0.36-1.47$ & 0.3816 \\
\hline Female & $\begin{array}{c}8 / 48 \\
(16.1)\end{array}$ & & & & $\begin{array}{l}22 / 48 \\
(45.8)\end{array}$ & & & & $\begin{array}{c}24 / 48 \\
(50)\end{array}$ & & & \\
\hline
\end{tabular}

+, Number of positive animals; $\mathrm{N}$, number of samples per variable; OR, odds ratio; $95 \% \mathrm{CI}$, 95\% confidence interval.

the urban area (UA) were seropositive for at least one tick-borne disease agent, and were 13.7 times more likely to be seropositive than those living in rural areas (RA). Besides, previous studies have shown a wide variation in seroprevalence for different TBD agents, such as E. canis, B. vogeli and B. burgdorferi, in different regions of Brazil (LABARTHE et al., 2003; CARLOS et al., 2007, SPOLIDORIO et al., 2010), but analyses were performed individually for each agent, and thus, there is no data to compare the overall seroprevalence found.

The higher seroprevalence found in the present study in dogs from UA was mainly due to seropositivity to E. canis $(64.7 \%)$ and B. vogeli (60.3\%), both agents transmitted by $R$. sanguineus ticks. Animals living in urban areas have a higher chance of becoming infested with $R$. sanguineus ticks than dogs dwelling rural areas (LABRUNA et al., 2001). This fact was supported by the present study, where $70 \%$ of the dogs from UA were infested by ticks, with $98.3 \%$ of these identified as $R$. sanguineus. High infestation rates of $R$. sanguineus have been shown to increase the risk of attack to humans (USPENSKY; IOFFE-USPENSKY, 2002). A previous study, also performed in the municipality of Londrina, showed that owners of tick-infested dogs were 3.2 times more likely to have removed ticks from themselves (TRAPP et al., 2006). Thus, there is a potential risk of human infection by TBD agents in the UA studied.

In this study, $60.3 \%$ of the dogs from UA were seropositive for B. vogeli. Lower seroprevalence data $(35.7 \%)$ were obtained in a hospital population of dogs in the same study area (TRAPP et al., 2006). A previous study showed no difference in seroprevalence for B. canis between rural $(46.5 \%)$ and urban $(42.9 \%)$ areas in the State of Espirito Santo (SPOLIDORIO et al., 2010). In the present study, dogs from UA were 3.1 times more likely to be seropositive to $B$. vogeli than those from RA ( $\mathrm{p}=0.0012)$. However, association between age, sex, gender and seropositivity to $B$. vogeli was not observed (Table 1). The difference in seroprevalence found in other studies may have been due to climatic variation, population studied, diagnostic test used, and the cut-off used in the IFAT to $B$. vogeli.

Dogs from UA were 5.29 times more likely to be seropositive to E. canis than dogs from RA $(\mathrm{p}<0.05)$. Besides, higher percentage of tick infestation have been found in dogs from UA $(70.6 \%)$ than those from RA $(50 \%)(\mathrm{p}=0.0135)$, which may explain the seroprevalence difference; association between seropositivity to E. canis and the presence of ticks was not observed ( $\mathrm{p}=0.9192)$. However, the relatively small number of samples analyzed has limited statistical power and thus, differences might have been missed. Serological surveys of $E$. canis in dogs have found seroprevalence data ranging from $4.8 \%$ to $38 \%$ and from $24.7 \%$ to $65.6 \%$ in urban and rural areas, respectively, using different methods, such as IFAT and ELISA (VIEIRA et al., 2011). The commercial ELISA rapid test used in this study utilizes synthetic peptides from p30 and p30-1 outer membrane proteins of $E$. canis as antigen, and detects anti-E. canis and anti-E. chaffeensis antibodies (O'CONNOR et al., 2006; $\mathrm{SNAP}^{\circledR} 4 \mathrm{Dx}^{\circledR}$ product insert and IDEXX Laboratories, unpublished data). In a previous study, the assay was able to identify only $30 \%$ of the serum samples from dogs with low-titer (80 to 160 ) on E. canis-IFA, but identified all dogs with titers $>320$ (O'CONNOR et al., 2006). Thus, seroprevalence for E. canis in dogs from the studied areas may be higher, since dogs with low titers may not have been recognized when a point-of-care ELISA 
assay was used, as previously described in dogs from an animal shelter in central Spain (COUTO et al., 2010).

Antibodies against $A$. phagocytophilum were found in $13.8 \%$ of the dogs using the commercial ELISA. Different results were found in dogs from the United States, France and Central Spain, which reported seroprevalence data of 4.8\%, 2.72\%, and $19 \%$ (BOWMAN et al., 2009; PANTCHEV et al., 2009; COUTO et al., 2010), respectively. Although $A$. phagocytophilum infection was reported in dogs from the State of Rio de Janeiro, southeastern Brazil, by a quantitative real-time PCR followed by sequencing of the $m s p 2$ gene (SANTOS et al., 2011), no serological data regarding this agent have been reported for Brazilian dogs to date. It is worth mentioning that the results found in the present study may be due to the cross-reactivity between $A$. phagocytophilum and $A$. platys in the assay used (CHANDRASHEKAR et al., 2010; SNAP $^{\circledR} 4 \mathrm{Dx}^{\circledR}$ product insert and IDEXX Laboratories, unpublished data). Using the same commercial ELISA rapid test in serum samples from 16 PCR-positive to $A$. platys dogs, in acute stage of disease, cross-reaction between these two bacteria was not found (FERREIRA et al., 2008). Unfortunately, PCR was not performed in the present study and it was not possible to establish whether antibodies detected were due to $A$. phagocytophilum or $A$. platys. Further studies should be conducted in order to elucidate the cross-reactivity between $A$. phagocytophilum and $A$. platys.

\section{Conclusion}

From two different populations, it was possible to determine seroprevalence data of two major tick-borne disease agents, E. canis and $B$. vogeli, which cause severe clinical illness in dogs in Brazil. Moreover, the findings of this study indicate a higher potential risk for dogs exposure to TBD pathogens in urban than in rural areas.

\section{Acknowledgements}

The authors are grateful to the "Coordenação de Aperfeiçoamento de Pessoal de Nível Superior" (CAPES) for the fellowship to Dr. Thállitha Vieira at the time of research. This study was supported by "Fundação Araucária do Paraná". The authors are also grateful to IDEXX Laboratories Inc. for providing the $\mathrm{SNAP}^{\circledR} 4 \mathrm{Dx}^{\circledR}$ kits.

\section{References}

Abel IS, Marzagão G, Yoshinari NH, Schumaker TTS. Borrelia-like spirochetes recovered from ticks and small mammals collected in the Atlantic forest reserve, Cotia County, State of São Paulo, Brazil. Mem Inst Oswaldo Cruz 2000; 95(5): 621-624. PMid:10998210. http://dx.doi. org/10.1590/S0074-02762000000500006

Amusategui I, Tesouro MA, Kakoma I, Sainz A. Serological reactivity to Ehrlichia canis, Anaplasma phagocytophilum, Neorickettsia risticii, Borrelia burgdorferi and Rickettsia conorii in dogs from Northwestern Spain. Vector Borne Zoonotic Dis 2008; 8(6): 797-803. PMid:18597660. http://dx.doi. org/10.1089/vbz.2007.0277

Aragão HB, Fonseca F. Notas de Ixodologia: VIII. Lista e chave para os representantes da fauna ixodológica brasileira. Mem Inst
Oswaldo Cruz 1961; 59(2): 115-129. PMid:13861962. http://dx.doi. org/10.1590/S0074-02761961000200001

Barros-Battesti DM, Yoshinari NH, Bonoldi VLN, Gomes AC. Parasitism by Ixodes didelphidis and I. loricatus (Acari: Ixodidae) on small wild mammals from an Atlantic forest in the State of Sao Paulo, Brazil. J Med Entomol 2000; 37(6): 820-827. PMid:11185614. http://dx.doi. org/10.1603/0022-2585-37.6.820

Bowman D, Little SE, Lorentzen L, Shields J, Sullivan MP, Carlin EP. Prevalence and geographic distribution of Dirofilaria immitis, Borrelia burgdorferi, Ehrlichia canis, and Anaplasma phagocytophilum in dogs in the United States: Results of a national clinic-based serologic survey. Vet Parasitol 2009; 160(1-2): 138-48. PMid:19150176. http://dx.doi. org/10.1016/j.vetpar.2008.10.093

Burgdorfer W, Hayes SF, Corwin D. Pathophysiology of the Lyme Disease spirochete, Borrelia burgdorferi, in ixodid ticks. Clin Infect Dis 1989; 11(S): 1442-1450.

Carlos RSA, Muniz Neta ES, Spagnol FH, Oliveira LLS, Brito RLL, Albuquerque GR, et al. Frequência de anticorpos anti-Erhlichia canis, Borrelia burgdorferi e antígenos de Dirofilaria immitis em cães na microrregião Ilhéus-Itabuna, Bahia, Brasil. Rev Bras Parasitol Vet 2007; 16(3): 117-120. PMid:18078596. http://dx.doi.org/10.1590/ S1984-29612007000300001

Chandrashekar R, Mainville CA, Beall MJ, O'Connor T, Eberts MD, Alleman AR, et al. Performance of a commercially available in-clinic ELISA for the detection of antibodies against Anaplasma phagocytophilum, Ehrlichia canis, and Borrelia burgdorferi and Dirofilaria immitis antigen in dogs. Am J Vet Res 2010; 71(12): 1443-50. PMid:21117995. http:// dx.doi.org/10.2460/ajvr.71.12.1443

Couto CG, Lorentzen L, Beall MJ, Shields J, Bertolone N, Couto JI, et al. Serological study of selected vector-borne diseases in shelter dogs in Central Spain using point-of-care assays. Vector Borne Zoonotic Dis 2010; 10(9): 885-888. PMid:20420531. http://dx.doi.org/10.1089/ vbz. 2009.0063

Dagnone AS, Souza AI, André MR, Machado RZ. Molecular diagnosis of Anaplasmataceae organisms in dogs with clinical and microscopical signs of ehrlichiosis. Rev Bras Parasitol Vet 2009; 18(4): 20-25. PMid:20040204. http://dx.doi.org/10.4322/rbpv.01804004

Dantas-Torres F. Canine vector-borne diseases in Brazil. Parasit Vectors 2008; 1(1): 25. PMid:18691408 PMCid:2533296. http://dx.doi. org/10.1186/1756-3305-1-25

Ferreira RF, Cerqueira AMF, Pereira AM, Velho PB, Azevedo RRM, Rodrigues ILD, et al. Avaliação da ocorrência de reação cruzada em cães PCR-positivos para Anaplasma platys testados em ELISA comercial para detecção de anticorpos de Anaplasma phagocytophilum. Rev Bras Parasitol Vet 2008; 17(S1): 5-8. PMid:20059806.

Figueiredo LT, Badra SJ, Pereira LE, Szabo MP. Report on ticks collected in the Southeast and Mid-West regions of Brazil: analyzing the potential transmission of tick-borne pathogens to man. Rev Soc Bras Med Trop 1999; 32(6): 613-619. PMid:10881097. http://dx.doi.org/10.1590/ S0037-86821999000600002

Furuta PI, Oliveira TM, Teixeira MC, Rocha AG, Machado RZ, Tinucci-Costa MG. Comparison between a soluble antigen-based ELISA and IFAT in detecting antibodies against Babesia canis in dogs. Rev Bras Parasitol Vet 2009; 18(3): 41-45. PMid:19772774. http://dx.doi. org/10.4322/rbpv.01803007

Guimarães JH, Tucci HEC, Barros-Battesti DM. Ectoparasitos de importância veterinária. São Paulo: Editora Plêiade; 2001. 
Instituto Nacional de Meteorologia - INMET. Previsão de Consenso [online]. 2011. [cited May 2012]. Available from: http://www.inmet. gov.br/html/prev_tempo.php.

Labarthe N, Pereira MC, Barbarini O, McKee W, Coimbra CA, Hoskins J. Serologic prevalence of Dirofilaria immitis, Ehrlichia canis, and Borrelia burgdorferi infections in Brazil. Vet Therapeutics 2003; 4(1): 67-75. PMid:12756637.

Labruna MB, Souza SLP, Guimarães Junior JS, Pacheco RC, Pinter A, Gennari SM. Prevalência de carrapatos em cães de áreas rurais da regiáo norte do Estado do Paraná. Arq Bras Med Vet Zootec 2001, 53(5): 553556. http://dx.doi.org/10.1590/S0102-09352001000500007

Maia MG, Costa RT, Haddad JP, Passos LM, Ribeiro MF. Epidemiological aspects of canine babesiosis in the semiarid area of the state of Minas Gerais, Brazil. Prev Vet Med 2007; 79(2-4): 155-62. PMid:17210194. http://dx.doi.org/10.1016/j.prevetmed.2006.11.013

O'Connor TP, Hanscom JL, Hegarty BC, Groat RG, Breitschwerdt EB. Comparison of an indirect immunofluorescence assay, western blot analysis, and a commercially available ELISA for detection of Ehrlichia canis antibodies in canine sera. Am J Vet Res 2006; 67(2): 206-210. PMid:16454622. http://dx.doi.org/10.2460/ajvr.67.2.206

Pantchev N, Schaper R, Limousin S, Norden N, Weise M, Lorentzen L. Occurrence of Dirofilaria immitis and Tick-Borne Infections Caused by Anaplasma phagocytophilum, Borrelia burgdorferi sensu lato and Ehrlichia canis in Domestic Dogs in France: Results of a Countrywide Serologic Survey. Parasitol Res 2009; 105(S1): 101-114. PMid:19575231. http:// dx.doi.org/10.1007/s00436-009-1501-2

Ramos R, Ramos C, Araújo F, Oliveira R, Souza I, Pimentel D, et al. Molecular survey and genetic characterization of tick-borne pathogens in dogs in metropolitan Recife (north-eastern Brazil). Parasitol Res 2010; 107(5): 1115-1120. PMid:20680344. http://dx.doi. org/10.1007/s00436-010-1979-7

Santos F, Coppede JS, Pereira AL, Oliveira LP, Roberto PG, Benedetti $\mathrm{RB}$, et al. Molecular evaluation of the incidence of Ehrlichia canis, Anaplasma platys and Babesia spp. in dogs from Ribeirão Preto, Brazil. Vet J2009; 179(1): 145-148. PMid:17920967. http://dx.doi.org/10.1016/j. tvjl.2007.08.017
Santos HA, Pires MS, Vilela JAR, Santos TM, Faccini JLH, Baldani CD, et al. Detection of Anaplasma phagocytophilum in Brazilian dogs by real-time polymerase chain reaction. J Vet Diagn Invest 2011; 23(4): 770-774. PMid:21908321. http://dx.doi. org/10.1177/1040638711406974

Spolidorio MG, Labruna MB, Machado RZ, Moraes-Filho J, Zago AM, Donatele DM, et al. Survey for tick-borne zoonoses in the State of Espirito Santo, Southeastern Brazil. Am J Trop Med Hyg 2010; 83(1): 201-206. PMid:20595502 PMCid:2912600. http://dx.doi.org/10.4269/ ajtmh.2010.09-0595

Trapp SM, Dagnone AS, Vidotto O, Freire RL, Amude AM, Morais HS. Seroepidemiology of canine babesiosis and ehrlichiosis in a hospital population. Vet Parasitol 2006; 140(3-4): 223-230. PMid:16647817. http://dx.doi.org/10.1016/j.vetpar.2006.03.030

Uspensky I, Ioffe-Uspensky I. The dog factor in brown dog tick Rhipicephalus sanguineus (Acari: Ixodidae) infestations in and near human dwellings. Int J Med Microbiol 2002; 291(S33): 156-163. http://dx.doi. org/10.1016/S1438-4221(02)80030-3

Vieira RFC, Biondo AW, Guimarães AMS, Santos AP, Santo RP, Dutra LH, et al. Ehrlichiosis in Brazil. Rev Bras Parasitol Vet 2011; 20(1): 1-12. PMid:21439224. http://dx.doi.org/10.1590/ S1984-29612011000100002

Woldehiwet Z. The natural history of Anaplasma phagocytophilum. Vet Parasitol 2010; 167(2-4): 108-22. PMid:19811878. http://dx.doi. org/10.1016/j.vetpar.2009.09.013

Wong SS, Teng JL, Poon RW, Choi GK, Chan KH, Yeung ML, et al. Comparative evaluation of a point-of-care immunochromatographic test SNAP 4Dx with molecular detection tests for vectorborne canine pathogens in Hong Kong. Vector Borne Zoonotic Dis 2011; 11(9): 1269-1277. PMid:21612526. http://dx.doi. org/10.1089/vbz.2010.0265

Yoshinari NH, Abrão MG, Bonoldi VL, Soares CO, Madruga CR, Scofield A, et al. Coexistence of antibodies to tick-borne agents of babesiosis and Lyme borreliosis in patients from Cotia county, State of São Paulo, Brazil. Mem Inst Oswaldo Cruz 2003; 98(3): 311-318. PMid:12886408. http:// dx.doi.org/10.1590/S0074-02762003000300004 